\title{
UNIVERSAL PRIMERS FOR DETECTION OF COMMON BACTERIAL PATHOGENS CAUSING PROSTHETIC JOINT INFECTION
}

\author{
Pavel Sauer ${ }^{a}$, Jiří Gallo ${ }^{b}$, Michaela Kesselováa ${ }^{a}$ Milan Koláŕa, Dagmar Koukalováa \\ ${ }^{a}$ Institute of Microbiology, Faculty of Medicine, Palacký University, Teaching Hospital, Olomouc, Czech Republic \\ ${ }^{b}$ Department of Orthopaedics, Faculty of Medicine, Palacký University, Teaching Hospital, Olomouc, Czech Republic
}

Received: May 2, 2005; Accepted (with revisions): November 4, 2005

Key words: Ribosomal RNA/Bacterial detection/Universal primer/Nested-PCR/Prosthetic joint infection/Diagnostics

The diagnosis of low grade prosthetic joint infection is difficult and time consuming. Nested-PCR for universal bacterial DNA segments detection of "orthopaedic" bacteria was tested in a laboratory setting. This method is based on amplification of the $16 \mathrm{~S}$ bacterial ribosomal RNA coding sequences. 11 species of the most frequent bacterial pathogens (Staphylococcus aureus, Staphylococcus epidermidis, Streptococcus pyogenes, Streptococcus agalactiae, Enterococcus faecium, Enterococcus faecalis, Klebsiella pneumoniae, Escherichia coli, Proteus mirabilis, Pseudomonas aeruginosa, Serratia marcescens) involved in prosthetic joint infections were studied. All could be detected rapidly and sensitively by this method.

\section{INTRODUCTION}

Prosthetic joint infection (PJI) is a serious complication of total joint arthroplasty causing a high degree of morbidity in affected patients. In addition, it is a significant economic burden to any health care system. Currently, the frequency of infection after knee or hip arthroplasty ranges from below $1 \%$ to $5 \%$ with slightly higher figures in revision procedures. ${ }^{1}$

The bacteria most commonly isolated from PJIs include coagulase-negative staphylococci and Staphylococcus aureus, followed by streptococci, gram-negative bacilli and others. ${ }^{2}$ In general, early manifestation of PJI (within the first 1-3 postoperative months) seems to be associated with more virulent pathogens such as Staphylococcus aureus, and often produces a clearer clinical picture of infection. On the other hand, the indolent and shifty nature of late occurring infections is more typical of less virulent bacteria such as coagulase-negative staphylococci. ${ }^{3}$ Various algorithms have been proposed to improve joint sepsis diagnostics, including clinical, serological, microbiological, and imaging techniques. ${ }^{4}$

It has been suggested that one useful method for lowgrade prosthetic sepsis bacteria identification should be sensitive and specific enough to allow early and adequate therapy. Recent studies suggest that rapid detection systems can decrease costs associated with hospitalization and refine application of antibiotic treatment. ${ }^{5}$

Traditional cultivation methods are time consuming and are not able to detect very small amounts of bacteria occurring in some PJIs or due to antibiotic treatment. ${ }^{6}$ This is an argument for the utilization of molecular diagnostics relying on the presence of bacterial DNA. PCR methods are able to detect small amounts of pathogen (even deadones). There are different strategies to PCR amplification of bacterial DNA in clinical samples. The first based on usage of species-specific primers. This method lacks the ability to determine bacterial infection definitely. ${ }^{7}$ The second approach involves amplification of sequences found in all bacteria based on universal sequences common in bacteria. ${ }^{8}$ A number of primer systems for $16 \mathrm{~S}$ bacterial rRNA detection have been published but they differ in focus to examinant clinical material and pathogens. ${ }^{9}, 10,11,12$ The first study in periprosthetic infection diagnostics with the help of PCR methods was published by Levine et al. ${ }^{13}$ In the Czech Republic, diagnostic based on PCR detection was published in 1999 by Rozkydal et al..$^{14}$

In this report, the primer system is demonstrated, optimized and tested for the most common orthopaedic pathogens. It is sensitive enough, has broad specifity among bacteria and can be used for a vast range of materials from joint fluid to tissue specimens.

\section{MATERIALS AND METHODS}

\section{Bacterial isolates and extraction of DNA}

The pure bacterial isolates were collected from cultures of common clinical specimens obtained at The Institute of Microbiology, Teaching Hospital Olomouc and Faculty of Medicine, Palacký University and were identified using the diagnostic test kits ENTEROtest16, STAFYtest and NEFERMtest (Pliva-Lachema, Czech Republic). The investigated species of bacteria were Staphylococcus aureus (10 isolates), Staphylococcus epidermidis (7), Streptococcus pyogenes (4), Streptococcus agalactiae (4), Enterococcus faecium (2), Enterococcus faecalis (2), Klebsiella pneumoniae (2), Escherichia coli (2), Proteus mirabilis (1), Pseudomonas aeruginosa (1) and Serratia marcescens 
(1). For the isolation of DNA, the pure isolates were inoculated onto agar and incubated overnight at $37^{\circ} \mathrm{C}$. One colony of the studied bacterial species was taken for isolation of DNA and resuspended in lysis buffer $(10 \mathrm{mM}$ Tris; $0,3 \mathrm{M}$ sucrose; $5 \mathrm{mM} \mathrm{MgCl} ; 1 \%$ Triton X-100) and harvested by centrifugation ( $3000 \mathrm{rpm}, 15 \mathrm{~min})$. DNA was recovered from the resulting sample using the Lego DNA Isolation kit (Top-Bio, Czech Republic) according to the manufacturers instruction. Briefly, a pellet of the bacterial colony was resuspended in binding buffer, silica was added and mixed $10 \mathrm{~min}$ by vortexing. Then the sample was centrifuged (14 $000 \mathrm{rpm}, 2 \mathrm{~min}$ ), washed twice with washing buffer, acetone and then dried. DNA was purchased by elution with buffer $(10 \mathrm{mM}$ Tris- $\mathrm{HCl}, 1 \mathrm{mM}$ EDTA) and frozen at $-20^{\circ} \mathrm{C}$ for later usage.

\section{Nested PCR}

$16 \mathrm{~S}$ rRNA target sequences of common bacterial pathogens causing the most frequent orthopaedic problems were selected using internet gene database of The Institute for Genomic Research (TIGR) and compared with sequences obtained from other internet gene databases (GenBank, USA). Conservative segments were chosen using the MACAW programme and suitable universal oligonucleotide primer pairs were designed with the help of the PRIMER2 programme. The sequence of primers used was as follows: outer forward UNI_OL 5'GTGTAGCGGTGAAATGCG-3', outer reverse UNI_OR 5'-ACGGGCGGTGTGTACAA-3', inner forward UNI_IL 5'-GGTGGAGCATGTGGTTTA-3', inner reverse UNI_IR 5'-CCATTGTAGCACGTGTGT-3'.

A master mix of total volume $45 \mu$ was prepared as follows: $37,6 \mu 1 \mathrm{H}_{2} \mathrm{O} ; 5 \mu \mathrm{l} 10 \times$ reaction buffer; $0,4 \mu \mathrm{l}$ dNTPs ( $10 \mathrm{mM}$ each); $0,8 \mu \mathrm{l}$ of each primer $(100 \mu \mathrm{M})$ and $0,4 \mu \mathrm{l} \mathrm{Taq}$ polymerase $(5 \mathrm{U} / \mu \mathrm{l})(\mathrm{dNTPs}$ was obtained from Promega USA, other components from Top-Bio, Czech Republic). $5 \mu \mathrm{l}$ of DNA of tested bacterial isolate was added to master mix and overlaid with $50 \mu 1$ of mineral oil (Top-Bio, Czech Republic). Hot-start PCR on MiniCycler (MJ Research, USA) was performed. The method was composed of the following steps: $94^{\circ} \mathrm{C} 5 \mathrm{~min}$, $94{ }^{\circ} \mathrm{C} 1 \mathrm{~min}, 55^{\circ} \mathrm{C} 1 \mathrm{~min}$ for outer primer pair annealing and $72{ }^{\circ} \mathrm{C} 1 \mathrm{~min}$ for elongation. Cycles were repeated $30 \times$. $1 \mu \mathrm{l}$ from the first run for the second part of nested-PCR was used. Annealing temperature of inner primer pair was changed to $53,6^{\circ} \mathrm{C}$.

To avoid extraneous DNA contamination or residual DNA in Taq polymerase, master mix was preincubated with $50 \mathrm{U}$ of DNase I (Fermentas, Lithuania) for $30 \mathrm{~min}$ at $37{ }^{\circ} \mathrm{C}$. DNase I was furher denatured by heating at $95^{\circ} \mathrm{C}$ for $10 \mathrm{~min}$. Assumed amplicons with $709 \mathrm{bp}$ for outer primer pair and 287 bp for inner primer pair were visualized with ethidium bromide after gel electrophoresis in $2 \%$ agarose gel.

The sensitivity of the reaction was tested with concentration series of Staphylococcus aureus and Staphylococcus epidermidis DNA.

\section{RESULTS}

Primers UNI_OL, UNI_OR, UNI_IL and UNI_IR corresponding to universal bacterial regions of the $16 \mathrm{~S}$ rRNA gene of Staphylococcus aureus were expected to amplify DNA from chosen pathogenic bacteria. Designed primer pairs for nested-PCR were tested with 11 species ( 36 bacterial isolates) of the most frequent microbial orthopaedic pathogens and in all tested bacteria the $16 \mathrm{~S}$ rRNA parts were amplified. Amplicons of expected sizes $709 \mathrm{bp}$ and $287 \mathrm{bp}$ were detected after the first and the second run of nested-PCR (Figure 1). A master mix without template DNA and DNase I nontreated by preincubation, showed in the second run of nested-PCR band corresponding to requested amplicon for detection of universal bacteria (287 bp long). After preincubation with $50 \mathrm{U}$ of DNase I, this amplicon was

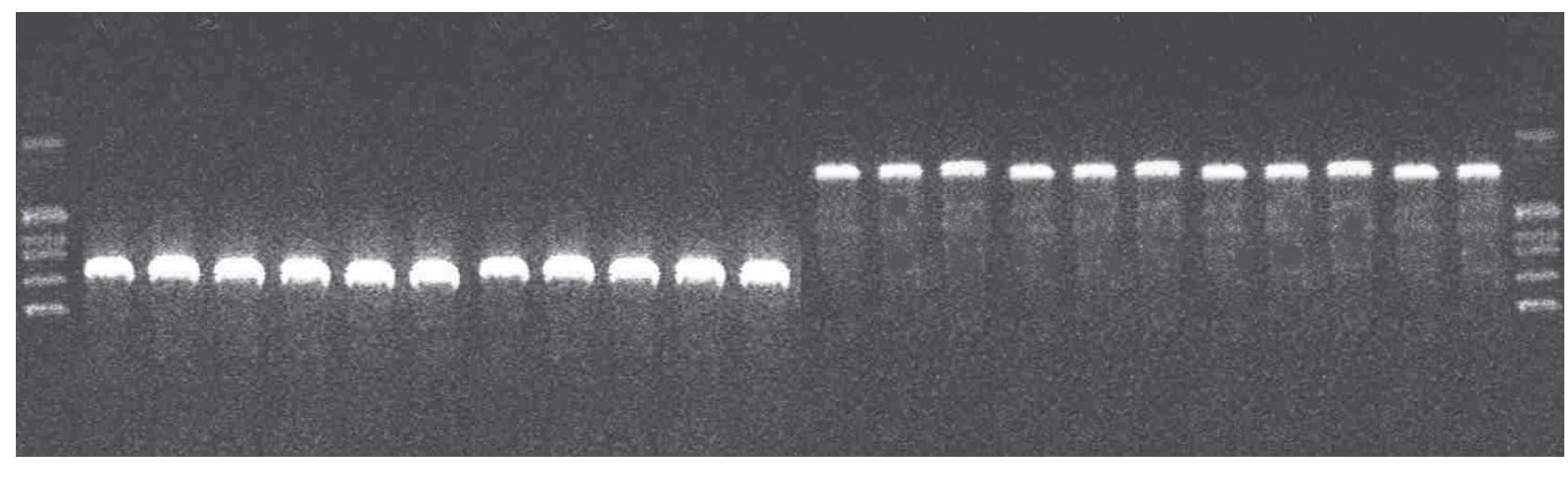

$\begin{array}{llllllllllllllllllllllll}1 & 2 & 3 & 4 & 5 & 6 & 7 & 8 & 9 & 10 & 11 & 12 & 13 & 14 & 15 & 16 & 17 & 18 & 19 & 20 & 21 & 22 & 23 & 24\end{array}$

Fig. 1. PCR detection of DNA from different bacterial cultures. Lanes 1 and 24, molecular weight marker (155, 447, 544, 595, 750, 970 bp). Lanes 2-12 show a 709 bp band, lanes 13-23 a 287 bp band corresponding to Staphylococcus aureus (2, 13); Staphylococcus epidermidis (3, 14), Streptococcus pyogenes (4, 15), Streptococcus agalactiae $(5,16)$, Enterococcus faecium (6, 17), Enterococcus faecalis (7, 18), Klebsiella pneumoniae (8, 19), Escherichia coli (9, 20), Proteus mirabilis (10, 21), Pseudomonas aeruginosa (11, 22), Serratia marcescens $(12,23)$. 
not visible. Detectable concentration of DNA isolated from Staphylococcus aureus and Staphylococcus epidermidis was 19 fg per $\mu 1,6$ fg per $\mu 1$ respectively.

\section{DISCUSSION}

It is well known that bacterial DNA or RNA can serve as an effective target for amplification and detection of bacterial DNA. ${ }^{15,16}$ Nevertheless the PCR-based assay may be so sensitive that is very easy to contaminate it regardless when during the pre-amplification or the post-amplification phase. The sources of false positive amplification may be at the site of specimen retrieval (commensal skin organisms) or during laboratory processing (reagents, pipettes, laboratory environment). Traces of DNA in Taq polymerase may be the source of false positivity too. ${ }^{17}$ Hence false positivity has frustrated researchers and clinicians due to unreliable interpretation of positive molecular results. To eliminate these problems, a number of recommendations (UV irradiation, DNase I or restriction endonucleases pretreatment, detection threshhold) and laboratory protocol advices have been published. ${ }^{18,19}$ Simultaneously, specific PCR configurations and complicated structure of inner controls were developed and tested. Mariani et al tested a protocol with preamplification DNase treatment and standard radioactive or non-radioactive labeling combined with Escherichia coli 16S rRNA gene as a probe. ${ }^{20}$ Later they published excellent clinical results for synovial fluid molecular analysis of PJI(ref. $\left.{ }^{21}\right)$. Hoeffel et al stressed the role of residual Escherichia coli DNA in commercially available products. ${ }^{22}$ They attempted to eliminate this false-positive amplification by developing so-called genus focused PCR primers designed not to hybridize and amplify Escherichia coli $16 \mathrm{~S}$ rRNA DNA. However, the results of this strategy were rather disillusioning (sensitivity $71 \%$, specificity $49 \%$ ). The results of our study strongly support the tactic using DNase I preamplification treatment as a more valid way to prevent false positive results. On the other hand, Meier et al treated their PCR master mix with ultraviolet radiation for 1 hour and obtained similar results. ${ }^{23}$ Based on these statements, there is evident that many ways achieve the same status, so the problem seems to be successfully solved.

PCR-based techniques have also been referred to the context of false negative results. This may occur due to the very high detection threshold of the method, failure in extraction of bacterial DNA or due to the presence of PCR inhibitors in clinical samples. Currently, clear recommendations for detection threshold do not exist. This ranges from 10 to more than 1000 colony forming units per cubic centimetre in published studies. ${ }^{24}$ However, this was beyond the scope of our study.

Our configuration of broad range nested-PCR is able to reliably detect the most common bacterial pathogens involved in prosthetic joint infection. According to clinical experiences the most relevant PJI pathogens are Staphylococcus aureus, Staphylococcus epidermidis and other coagulase-negative staphylococci. Other bacteria tested in the present study have been captured at a very low rate. Nevertheless, all eleven tested bacteria were identifiable by this approach and after PCR amplification two expected products $709 \mathrm{bp}$ and $287 \mathrm{bp}$ long were detected. The detection limit was 6 fg per $\mu 1$ and 19 fg per $\mu 1$ for Staphylococcus epidermidis and Staphylococcus aureus, respectively. No other main products were detected if the master mix was pretreated with DNase I. The source of false positivity was probably DNA contamination from Taq polymerase occurring under our laboratory settings. Non-treated master mix showed byproducts. To remove them, at least $50 \mathrm{U}$ of DNase I for one PCR tube was needed.

Based on this result it may be concluded that this method seems to be applicable for the detection of bacteria from joint fluid and tissue specimens. Simultaneously, there is a need to continue to test this procedure as part of well designed clinical studies.

\section{ACKNOWLEDGEMENT}

The study was supported by grant IGA No. NM7680 (Grant Agency of the Czech Ministry of Healthcare).

\section{REFERENCES}

1. Brause BD. (2003) Microbes and Antibiotics. In: The Adult Knee. Callaghan JJ, Rosenberg AG, Rubash HE, Simonian PT, Wickiewicz TL (ed). Vol II. Lippincott Williams and Wilkins, Philadelphia, 1493-1499.

2. Steckelberg JM, Osmon DR. (2000) Prosthetic joint infections. In: Infections associated with indwelling medical devices. Waldvogel FA, Bisno AL (ed). ASM Press, Washington, 173-179.

3. Gallo J, Koláŕ M, Riháková P, Tichá V. (2003) Pathogenesis of prosthesis-related infection. A review. Biomed Papers 147, 27-35.

4. Zimmerli W. (2000) Prosthetic joint infection: diagnosis and treatment. Curr Infect Dis Rep 2, 377-379.

5. Doern GV, Vautour M, Gaudet M, Levy B. (1994) Clinical impact of rapid in vitro susceptibility testing and bacterial identification. J Clin Microbiol 32, 1757-1762.

6. Trampuz A, Steckelberg JM, Osmon DR, Crockerill FR, III, Hanssen AD, Patel R. (2003) Advances in the laboratory diagnosis of prosthetic joint infection. Rev Med Microbiol 14, 1-14.

7. McCabe KM, McCabe ERB. (1997) Molecular genetic diagnosis of infectious diseases. Pediatr Ann 26, 547-552.

8. McCabe KM, Zhang YH, Khan G, Mason EO, McCabe ERB. (1995) Amplification of bacterial DNA using highly conserved sequences: Automated analysis and potential for molecular triage sepsis. Pediatrics 95, 165-169.

9. Ley BE, Linton CJ, Bennett DMC, Jalal H, Foot ABM, Millar MR. (1998) Detection of bacteraemia in patients with fever and neutropenia using 16S rRNA gene amplification by polymerase chain reaction. Eur J Clin Microbiol Infect Dis 17, 247-253.

10. Radstrom P, Backman A, Qian NY, Kragsbjerg P, Pahlson C, Olcen P. (1994) Detection of bacterial DNA in cerebrospinal fluid by an assay for simultaneous detection of Neisseria meningitidis, Haemophilus influenzae, and streptococci using a seminested PCR strategy. J Clin Microbiol 32, 2738-2744.

11. Carroll NM, Jaeger EEM, Choudhury S, Dunlop AAS, Matheson MM, Adamson P, Okhravi N, Lightman S. (2000) Detection and discrimination between Gram positive/Gram negative bacteria in intraocular samples using nested PCR. J Clin Microbiol 38, 1753-1757. 
12. Greisen K, Loeffelholz M, Purohit A, Leong D. (1994) PCR primers and probes for the 16S rRNA gene of most species of pathogenic bacteria, including bacteria found in cerebrospinal fluid. $\mathrm{J}$ Clin Microbiol 32, 335-351.

13. Levine MJ, Mariani BD, Tuan RS, Booth RE. (1995) Molecular genetic diagnosis of infected total joint arthroplasty. J Arthroplasty 10, 93-94.

14. Rozkydal Z, Benedík J, Tomáš T, Dendis M, Horváth R. (1999) Polymerase chain reaction in diagnosis of infection of total knee replacement. Acta Chir Orthop Traumatol Cech 65, 272-276.

15. Wilkinson NZ, Kingsley GH, Jones HW, Sieper J, Braun J, Ward ME. (1999) The detection of DNA from a range of bacterial species in the joints of patients with a variety of arthritides using a nested, broad-range polymerase chain reaction. Rheumatology 38, 260-266.

16. Klausegger A, Hell M, Berger A, Zinober K, Baier S, Jones N, Sperl W, Kofler B. (1999) Gram type-specific broad-range PCR amplification for rapid detection of 62 pathogenic bacteria. J Clin Microbiol 37, 464-466.

17. Newsome T, Li BJ, Zou N, Lo SC. (2004) Presence of bacteria phage-like DNA sequences in commercial Taq DNA polymerase reagents. J Clin Microbiol 42, 2264-2267.

18. Millar BC, Xu J, Moore JE. (2002) Risk assessment models and contamination management: Implications for broad-range ribo- somal DNA PCR as a diagnostic tool in medical bacteriology. J. Clin Microbiol 40, 1575-1580.

19. Heininger A, Binder M, Ellinger A, Botzenhart K, Unertl K, Doring G. (2003) DNase pretreatment of master mix reagents improves the validity of universal $16 \mathrm{~S}$ rRNA gene PCR results. J Clin Microbiol 41, 1763-1765.

20. Mariani BD, Levine MJ, Booth RE, Jr., Tuan RS. (1995) Development of a novel, rapid processing protocol for polymerase chain reaction-based detection of bacterial infections in synovial fluids. Mol Biotechnol 4, 227-237.

21. Mariani BD, Martin DS, Levine MJ, Booth RE, Jr., Tuan RS. (1996) The Coventry Award. Polymerase chain reaction detection of bacterial infection in total knee arthroplasty. Clin Orthop 331, 11-22.

22. Hoeffel DP, Hinrichs SH, Garvin KL. (1999) Molecular diagnostics for the detection of musculoskeletal infection. Clin Orthop 360, 37-46.

23. Meier A, Persing DH, Finken M, Bottgeri EC. (1993) Elimination of contaminating DNA within polymerase chain reaction reagents: Implications for a general approach to detection of uncultured pathogens. J Clin Microbiol 31, 646-652.

24. Rantakokko-Jalava K, Jalava J. (2002) Optimal DNA isolation method for detection of bacteria in clinical specimens by broadrange PCR. J Clin Microbiol 40, 4211-4217. 